\title{
Focus and Phrasing in Shingazidja
}

\section{Cédric Patin}

Zentrum für Allgemeine Sprachwissenschaft, Berlin \&

Laboratoire Phonétique et Phonologie, Paris

\section{$1 \quad$ Introduction $^{1}$}

In his seminal $\mathrm{PhD}$ thesis (Kanerva 1990), Jonni Kanerva has demonstrated that focus influences the prosodic phrasing in Chichewa, a Bantu language of Malawi. The core data are exemplified in (1). The symbol ')' signals the end of a phonological phrase ${ }^{2}$.

(1) Chicheŵa (Kanerva 1990: 98)

a. ( anaményá nyumbá ñó mwála ) (VP focus) he-hit House with rock

he hit the house with a rock

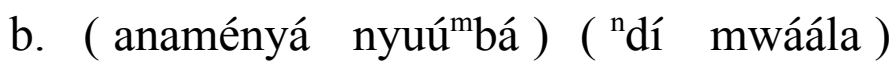

( Object focus ) he hit THE HOUSE with a rock

c. ( anaméenyá ) ( nyuúm bá ) ( ' dí mwáála )

( Verb focus ) he hit the house with a rock

In (1-a), all the elements of the VP (i.e. the verb anaményá 'he hit', the object $n y u^{m} b a$ ' 'house' and the oblique PP "di mwáála 'with a rock') form a single phonological phrase. In (1-b), however, the object is focused in-situ and is then followed by a prosodic break. Finally, in (1-c), the verb is focused and both the verb and the object are followed by a prosodic boundary. Similar results were independently observed in another dialect of Chichewa (Downing et al. 2005).

1 For helpful discussion of aspects of this work, I wish to thank Laura Downing, Gwendoline Fox, Charles Kisseberth, Emanuelle Mason, Gérard Philippson and Annie Rialland. Many thanks to my main informant, Ibrahim Barwane : this work could not have been done without his help.

2 Reffered to as focus phrase in Kanerva (1990) - see Downing (2002) for a discussion. 
It has been established since Kanerva's work that focus conditions phrasing directly or indirectly - in several other Bantu languages, e.g. Chimwiini (Kisseberth 2007, Downing 2002, Kisseberth \& Abasheikh 2004), Xhosa (Jokweni 1995, Zerbian 2004), Chitumbuka (Downing 2006, 2007), Zulu (Cheng \& Downing 2006, Downing 2007), Bemba (Kula 2007), etc.

In this paper, I will argue that focus also conditions phrasing in Shingazidja, a Bantu language ${ }^{3}$ spoken on Grande Comore (or Ngazidja, the largest island of the Comoros).

Many works have been dedicated to the tonology of Shingazidja. The bases of the system were firstly identified by Tucker \& Bryan (1970) and reanalysed by Philippson (1988). Later, Cassimjee \& Kisseberth (1989, 1992, 1993, 1998) provide a very convincing analysis of the whole system of the language, and my own research (Patin 2007a) shows a great correspondence with their results. However, little attention has been paid by these authors or others (Jouannet 1989, Rey 1990, Philippson 2005) to the phonology-pragmatics interface, especially on the relation between focus and phrasing. This paper thus proposes to explore this question. It will be claimed that focus, beside syntax, has an influence on phrasing in Shingazidja.

In his seminal thesis (Truckenbrodt 1995) and in a following article (Truckenbrodt 1999), Truckenbrodt has provided a very convincing analysis, sketched within Optimality Theory (now OT; Prince \& Smolensky 1993, McCarthy \& Prince 1993a, 1993b, and an abundant literature), of the Chichewia facts identified by Kanerva. I will adopt Truckenbrodt's model in this paper, showing that a minimal reranking of the hierarchy proposed by Truckenbrodt (1995, 1999) to account for Chichewa derives the correct phrasing of Shingazidja.

The paper is organised as follows: in section 2, I present the phonological processes that are relevant to identify prosodic boundaries in Shingazidja, and I identify some of the contexts in which the phrasing is syntactically determined. In section 3, I show how the focus influences the phonological phrasing in Shingazidja. In section 4, an OT analysis of the data presented in sections 2 and 3 is proposed.

3 Shingazidja is coded G44a in Guthrie (1967-71)'s referential classification. The language belongs to the Sabaki group, which also notably contains Kiswahili. Data for this paper, which were partially recorded, were mostly obtained from the native speaker Ibrahim Barwane in Paris (France), between June 2006 and January 2007. 


\section{Phrasing in Shingazidja}

Evidence for phrasing in Shingazidja comes from the shift of tone. In this language, a high tone will shift to the syllable preceding another tone bearing syllable (see section 2.1), the last syllable of a phonological phrase (see section 2.2) or the penultimate syllable of an intonational phrase (see section 2.3). Indeed, Shingazidja is typologically interesting since it clearly presents two prosodic levels above the level of the prosodic word, while such an evidence does not exist in many other Bantu languages (see Zerbian 2006: 130 for a discussion). Most of the results of this section were previously identified by Cassimjee \& Kisseberth (1993). Due to space restrictions, I will not discuss in this paper all the contexts in which phrasing is conditioned by morphosyntactic parameters see Patin (2007a: chapter 5) for a detailed list of the relevant contexts.

\subsection{Tone phenomena}

Shingazidja, similarly to other genetically related languages like Mijikenda (E72-73, a set of nine dialects mostly spoken in eastern Kenya; see Philippson 1991, Cassimjee \& Kisseberth 1998), exhibits an 'unbounded' tone shift phenomenon. In (2-a), the noun walevi 'drunkards' has a high tone on its final syllable in isolation ${ }^{4}$. In (2-b-i), however, the tone originally associated to the last syllable of this same noun waleví shifts onto the penultimate syllable of the adjective waili ' $t w o$ '. The noun, which underlyingly bears a high tone on its last syllable, is then fully low. In (2-c-i), the noun receives the shifted tone of the verb hawóno 'he saw'.

a. wa-leví

$2^{5}$-drunkard

drunkards

b. i. wa-levi wa-1́li

2-drunkard 2-two

two drunkards

ii. *waleví wailí

4 I mark the trigger syllable which underlyingly bears the tone by underlining it.

5 Numbers refer to noun classes. 
c. i. ha-wono wa-lévi

$3 \mathrm{sg}$ (past)-see 2-drunkard

he saw drunkards

ii. *hawóno waleví

The shift of the first tone leads to the deletion of the second one. In (2-c-i), the tone of the last syllable of walevi 'drunkards' is deleted because it is adjacent to the tone of the verb, which surfaces on the penultimate syllable of the noun. This deletion is triggered by the Obligatory Contour Principle (now OCP), which prevents the adjacency of two identical elements - here, two high tones. In a sequence of high tones, then, the first one shifts to the syllable preceding the following one, and every other tone is deleted - *hawono waléví.

Compare for instance (2-b-i) with (3). In (2-b-i), the shift of the tone of the noun walevi ' drunkards' causes the deletion of the tone of the adjective wailí 'two'. In (3), however, the tone of the adjective is free to appear in surface since the tone of the noun is deleted.

$\begin{array}{lll}\text { ha-wono walévi } & \text { wailí } \\ \text { 3sg(past)-see } & \text { 2-drunkard } & \text { 2-two } \\ \text { he saw two drunkards } & \end{array}$

If the noun does not underlyingly bear a high tone - e.g. ndóvu 'elephant' in (4) - , the tone of the verb shifts to the adjective. As with the noun, the lexical tone of the adjective mbili ' 'two' is then deleted.

$\begin{array}{lll}\text { ha-wono } \quad \text { n-dovu } & \text { m-6íli } \\ 3 \operatorname{sg} \text { (past)-see } & 10 \text {-elephants } & 10 \text {-two } \\ \text { he saw two elephants } & \end{array}$

\subsection{Phonological phrases}

In Shingazidja, the maximal syntactic phrase and the phonological phrase are coextensive. For instance, in (5), the whole $\mathrm{NP}^{7}$ forms a single phonological

6 In Shingazidja, a phonological phrase has to present at least one tone. The tone that appears on this noun when it is isolated is a default one.

7 In Shingazidja, an isolated NP is frequently preceded by the so-called 'stabilizer' (here $n d e)$, which also introduces clefts. What is important here is that no obligatory prosodic boundary has to be inserted within the NP. 
phrase, despite its heaviness ${ }^{8}$. The symbol ') $)_{\Phi}$ ' signals the end of a phonological phrase.

(5) ( nde zé m-bưưa m-6ilí n-jẹu halissi z-á hahe ) $\Phi$

STAB $\mathrm{AT}_{10} 10$-stick 10-two 10-white very 10-of his

these are his two very white sticks

Similarly, a VP constitutes a single phonological phrase (6-a), even if it contains two object NPs - (6-b).

a. ( tsi-wono n-dovu y-a wá-mezi $)_{\Phi}$

1sg(past)-see 9-elephant 9-of 2-beggar

I saw an elephant of the beggars

b. ( ha-nika nama mi-du-mí- $\left.\int_{\text {e }}\right)_{\Phi}$

$3 \mathrm{sg}$ (past)-give 9/meat 1-person-1-woman

he gave (some) meat to a woman

In (6-a), the tone of the verb tsiwóno shifts onto the first syllable of the genitive noun wamézzi. This means that no prosodic boundary separates the verb from the NP.

The same goes for (6-b), where the tone of the verb haníka shifts onto the penultimate syllable of the second object $m q u-m, \underline{e}$.

However, a subject NP phrases separately from the VP. In (7-a), the tone of the subject noun mlimádji 'farmer' does not shift on the first syllable of the verb.
a. ( mi-limąjí $)_{\Phi}$ ( ha-remé paha $)_{\Phi}$ 1 -farmer $3 \mathrm{sg}$ (past)-beat (5-)cat a farmer beat a cat

b. *( mlimadji háreme páha $)_{\Phi}$

8 Some boundaries may be inserted depending on rhythm, speech rate, word order and branchingness parameters that I have not identified precisely enough at this point of my research. Still, the presence of these boundaries is not obligatory. 
The prosodic system also presents several complications since some function words are preceded by a phonological phrase boundary. In (8-b) and (8-c), one of the objects is preceded by a so-called augment, a deictic that is related to definiteness/referentiality in Shingazidja. In (8-b), the tone of the verb cannot shift onto the augment or the following noun. This indicates that the augment is preceded by a phonological phrase boundary.

a. ( ha-nika júmbạ m-leví $)_{\Phi}$ $3 \mathrm{sg}$ (past)-give (9-)house 1-drunkard he gave a house to a drunkard

b. $(\text { ha-niká })_{\Phi} \quad(\text { e jumbạ m-lévi })_{\Phi}$ 3sg(past)-give $\quad \mathrm{AT}_{9}$ (9-)house 1-drunkard he gave the house to a drunkard

c. ( ha-nika júmbạ $)_{\Phi}(\mathrm{e} \text { m-leví })_{\Phi}$ $3 \mathrm{sg}$ (past)-give (9-)house $\mathrm{AT}_{1}$ 1-drunkard he gave a house to the drunkard

Those facts are beyond the scope of this paper and will not be discussed here in detail (see Patin 2007a for this issue).

\subsection{Intonational phrases}

In (9-a), the tone of the verb - which is prosodically separated from the subject shifts on the penultimate syllable of the object tunda 'orange', not on its last syllable (9-b). On the contrary, the tone of the penultimate syllable of the subject noun mwána 'child' shifts to the following syllable, which is the last of the phonological phrase.
a. ( e mw-âná $)_{\Phi} \quad($ ali
túnda $)_{\Phi}$
$\mathrm{AT}_{1}$ 1-farmer
$3 \mathrm{sg}$ (past)-eat (5-)orange
the child ate an orange

b. *( e mwaná $)_{\Phi}(\text { ali tundá })_{\Phi}$ 
The last syllable of a clause, in Shingazidja as in many other Bantu languages, has a special prosodic status. In Shingazidja, the last syllable of a clause cannot be a target for a shifted tone 9 . This restriction, refered here as extraprosodicity, indicates that, in Shingazidja, two different prosodic levels exist above the prosodic word: the phonological phrase and the intonational phrase. The former is the domain of tone shift. The later is characterised by (i.) the extraprosodicity of its last syllable (ii.) by the lowering of the last tone of the group.

In (9-a), the fact that the tone of the subject can shift on its last syllable shows that the subject NP and the VP are not separated by an intonational phrase boundary. Besides, the extraprosodicity does not characterise the end of the VP. If the subject is postposed to the $\mathrm{VP}^{10}(10)$, the last syllable of the former - being then the last syllable of the clause - is thus extraprosodic, while the last one of the latter - i.e. the object - receives the tone of the verb.

$$
\begin{aligned}
& \text { ( ali tundá })_{\Phi} \quad(\mathrm{e} \quad \text { mw-ána })_{\Phi} \\
& 3 \mathrm{sg} \text { (past)-eat (5-)orange } \mathrm{AT}_{1} \text { 1-child } \\
& \text { the child ate an orange }
\end{aligned}
$$

The domain of the intonational phrase is then wider than the syntactic phrase (now XP) in broad-focus sentences. Most of the time, the intonational phrase corresponds to the whole utterance but its length varies considerably, depending on focus-related parameters (cf. section 3.2).

A more precise representation of the examples (9-a) and (10) is then proposed in (11). ' $)_{I}$ ' signals the end of an intonational phrase.

(11) a. ( ( e mwaná $)_{\Phi}$ ( ali túnda $\left.)_{\Phi}\right)_{I}$

the child ate an orange - cf. (9-a)

b. ( ( ali tundá $\left.)_{\Phi}(\text { e mwána })_{\Phi}\right)_{I}$

the child ate an orange - cf. (10)

To sum up, it has been said in this section that two different prosodic levels exist above the prosodic word level in Shingazidja. The first one is the phonological phrase level, generally corresponding to the XP, and it is determined by tone

9 Note however that a lexical tone associated to the last syllable of a clause, if not deleted following OCP phenomena, is maintained - cf. (3) or (8-a).

10 SVO is the unmarked word order. VOS, even though rarely found, is also possible. Other orders are only possible if the verb presents an object marker - i.e. a resumptive pronoun. 
shift. The second one is the intonational phrase level and is most of the time coextensive with the whole utterance. However, morphosyntactic parameters are not enough to account for all the phrasing situations observed in Shingazidja, as it will be demonstrated in the following section.

\section{Focus and Phrasing}

In the preceding section, I showed that phrasing is conditioned by syntactic considerations in Shingazidja. This section explores the influence of focus on phrasing. Following Jackendoff (1972), Watters (1979) and many others, I will consider in this paper that focus denotes the information that is assumed by the speaker not to be (entirely) shared by him and the hearer.

First, I will show that focus is expressed by phonological phrasing in Shingazidja. Then, I will briefly explain how intonational phrases are driven by the contrastive focus.

\subsection{Narrow focus}

This section discuss the influence of focus on phrasing in Shingazidja. At this point of my research, I did not found evidence that focus may be expressed by a specific word or morpheme, or by a specific word order ${ }^{11}$.

\subsubsection{Narrow focus and phonological phrases}

In the previous section, it has been claimed that a maximal syntactic phrase basically corresponds to one phonological phrase in Shingazidja. However, any lexical item ${ }^{12}$ may be focused in situ by being followed by a phonological phrase boundary.

For instance, while the VP constitutes a single phonological phrase in (12a), the in situ focused noun is prosodically separated from its genitive modifier in (12-b).

$$
\begin{aligned}
& \text { a. ( tsi-wono n-dovu y-a wá-mezi })_{\Phi} \\
& 1 \mathrm{sg} \text { (past)-see 9-elephant 9-of 2-beggar } \\
& \text { I saw an elephant of the beggars }
\end{aligned}
$$

11 Variations in word order seem to be linked to topicalisation or stylistic parameters.

12 To focus a grammatical element (e.g. an augment) or a morpheme, other strategies - the insertion of a tone (briefly discussed in Patin 2007b), or an intensity peak - seem to be selected. Further research will be necessary to identify precisely the nature and the range of these alternative strategies. 
b. $(\text { tsiwono ndovú })_{\Phi}$ ( ya wamézi $)_{\Phi}$

I saw an ELEPHANT of the beggars

(answering the question: what did you see of the beggars?)

In (12-b), the tone of the verb tsiwóno shifts to the last syllable of the head noun $n d o v v$ while it shifts up to the genitive noun in (12-a). This means that there is a phonological phrase boundary following the head noun in (12-b). The presence of this boundary seems to be obligatory in this context.

\subsubsection{Object focus}

To focus the first object of a VP, it is necessary to place a phonological phrase boundary after it. Compare for instance (13-a) with (13-b).
a. ( ha-nika n-dovu mlévi $)_{\Phi}$ (VP focus)
$3 \mathrm{sg}$ (past)-give 9-elephant 1-drunkard
he gave an elephant to a drunkard

b. $(\text { hanika ndovú })_{\Phi}\left(\operatorname{mlevi}^{13}\right)_{\Phi}$

(object focus)

he gave an ELEPHANT to a drunkard

(answering the question: what did he gave to a drunkard?)

In (13-a), the tone of the verb hanika shifts to the penultimate syllable of the second object of the VP. In (13-b), however, the shift stops on the last syllable of the first one, indicating that the first object is followed by a prosodic break.

This result is comparable to what was observed in Chichewa - see (1-b) above - or in Bemba. In this language, a low tone marks the end of the phonological phrase ${ }^{14}$. In (14-b), a low tone appears on the last syllable of the focused object, indicating that it is followed by a prosodic break.

13 When a single word follows a focused element, it tends to loose its lexical tone - but see (15-a-ii).

14 Referred to as a major phrase in Kula (2007). In (14), SM is used for subject marker and TNS for tense. 
(14) Bemba

(Kula 2007: 203)

a. ( n-alí-mónóómwááná mucímuti $)_{M a P}$

(VP focus)

1SM-TNS-see.1child 18tree

I saw a child in the tree

b. ( n-alí-mónóómwáána $)_{M a P}$ ( mucímuti $)_{M a P}$

(object focus)

1SM-TNS-see.1child

18tree

I saw a child in the tree

\subsubsection{Verb focus}

As expected from the data above, a focused verb is also separated from its complements with a prosodic break. Compare for instance (15-a-i) and (15-b-i) with, respectively, (15-a-ii) and (15-b-ii).

(15)
a. i. ( ha-piha
djánze $)_{\Phi}$

$3 \mathrm{sg}$ (past)-cook (5-)crab

he cooked a crab

ii. ( hapihá $)_{\Phi} \quad(\text { djanzé })_{\Phi}$

he COOKED $a \mathrm{crab}$

b. i. ( tsi-wono má-ßạaha ma-ili y-á hahe $)_{\Phi}$

$1 \operatorname{sg}($ past)-see 6-cat 6-two 6-of his

I saw his two cats

ii. ( tsiwonó $)_{\Phi}$ ( maßaha maíli ya háhe $)_{\Phi}$ I SAW his two cats

In both (15-a-ii) and (15-b-ii) the tone of the focused verb is not allowed to shift on the object noun. Again, this is consistent with what has been said in the previous sections, or with what was observed in other Bantu languages.

However, Shingazidja differs from Chichewa on a particular point. Remember that in this language - see (16), extracted from (1) - a prosodic break is inserted between two objects when the verb is focused. 
(16) Chicheŵa

( anaméenyá ) ( nyuứmbá ) ( ' dí mwáála )

HE HIT the house with a rock

(Kanerva 1990: 98)

In Shingazidja, however, the first object of a VP does not phrase separately from the second one if the verb is focused - (17-b).
(17)
a. ( ha-nika júm6a m-leví $)_{\Phi}$
$3 \operatorname{sg}$ (past)-give (9-)house 1-drunkard
he gave a house to a drunkard
b. ( haniká $)_{\Phi}$ ( numbạ mlévi $)_{\Phi}$
(verb focus)
HE GAVE $a$ house to a drunkard

In (17-b), the tone of the verb does not shift on the first object - as in (17-a) since the verb is followed by a prosodic break. However, the tone of the first object jum bá shifts on the penultimate syllable of the second object mleví.

On this particular point Shingazidja differs from Chichewa and behaves like Chitumbuka. In this language too, both objects of a VP will phrase together (18).

(18) Chitumbuka

(Downing 2006: 72)

( $[\beta] a-m b w e ́ e n g u)$ ( [ $\beta] a-k u-l y a ́ a-s o)$ ( ma-gwáfya m-ma-kúuni ) 2-monkey 2-tam-eat-again 6-guavas in-6-trees

The monkeys are eating again the guavas in the trees

The major correlate of phrasing in Chitumbuka is the lengthening of the penultimate syllable of a phonological phrase. In (18), the subject has a long penultimate, since it does not phrase with the VP as in Shingazidja. The last word of the clause also presents a long penultimate, so does the verb, because it ends with the focus particle - so. However, the absence of length on the penultimate syllable of the object magwáfya indicates that this word is not followed by a prosodic break.

\subsection{Contrastive focus}

In the previous section, it has been said that a focused lexical word is followed by a phonological phrase boundary (19-b), which stops the shift of the tone. 
However, if a word bears a contrastive focus, a shifted tone does not stop on its last syllable, but on its penultimate syllable (19-c). In Shingazidja, an intonational phrase boundary is added at the right of a word that bears a contrastive focus.

a. ( ( tsi-wono n-dovu y-a wá-mezi $\left.)_{\Phi}\right)_{I}$

1sg(past)-see 9-elephant 9-of 2-beggar

the child ate an orange - cf. (9-a)

b. ( ( tsi-wono ndovú $)_{\Phi}$ ( ya wa-mézi $\left.)_{\Phi}\right)_{I}$

I saw an ELEPHANT of the beggars

(answering the question: what did you see of the beggars?)

c. $\left((\text { tsi-wono ndóvu })_{\Phi}\right)_{I}$ ( ( ya wa-mézi $\left.)_{\Phi}\right)_{I}$

No !) I saw an ELEPHANT of the beggars

(answering the question: did you see the horse of the beggars?)

In the section 2.3, I claimed that the intonational phrase level is marked in Shingazidja by the extraprosodicity of its last syllable. In (19-c), the tone of the verb tsi-wóno stops on the penultimate syllable of $n d o ́ v u$, and does not shift on the last syllable of the noun. Since ndóvu has no underlying tone on its last syllable, it means that the last syllable is 'extraprosodic'. Thus, the word ndóvu is the last word of an intonational phrase. Evidence for such an analysis is the optional presence of a pause after the focused item in sentences like (19-c).

\section{An OT analysis of phrasing in Shingazidja}

In this section, I will provide an OT analysis of the data presented in the previous sections. I will only discuss here broad-focus and narrow-focus situations.

First (sections 4.1 and 4.2), I will discuss broad-focus sentences, showing that Shingazidja may be accounted for using alignment constraints (Selkirk 1995) and the constraint WRAP-XP proposed by Truckenbrodt (1995, 1999). Then (sections 4.3 and 4.4), situations that involve a narrow focus will be analysed, using another constraint proposed by Truckenbrodt: Align Foc. I will insist on the verb-focus sentences, where Shingazidja differs from Chicheŵa. 


\subsection{Broad- focus sentences: basic phrasing}

Based on previous works by Clements (1978) and Chen (1985), Selkirk (1986) and Selkirk \& Shen (1990) proposed a model called end-based theory. This model aligns the right or left ${ }^{15}$ edge of phonological phrases with the right or left edge of syntactic XPs. Later, Selkirk (1995) has reanalysed her model in the format of Optimality Theory, and has reformulated the parameters as alignment constraints. These constraints are presented in (20).

(20) Alignment constraints (Truckenbrodt 1999: 223, following Selkirk 1995: 469, 477)

a. Align-XP, R: $\operatorname{Align}(X P, R ; P, R)$

For each $\mathrm{XP}$ there is a $\mathrm{P}$ such that the right edge of $\mathrm{XP}$ coincides with the right edge of $P$

b. Align-XP, L: Align (XP, L; P, L)

For each XP there is a $\mathrm{P}$ such that the left edge of XP coincides with the left edge of $\mathrm{P}$

In Shingazidja, the subject NP phrases separately from the VP (21).

$$
\begin{aligned}
& (\text { m-leví })_{\Phi} \quad(\text { ha-djá })_{\Phi} \\
& \text { 1-drunkard } \quad 3 \operatorname{sg}(\text { past)-come } \\
& \text { a drunkard came }
\end{aligned}
$$

To account for the prosodic pattern of sentences like (21), I will consider that the constraint Align-XP,R (cf. 20-a) is dominant in Shingazidja. Such an analysis was previously proposed to account for several other Bantu languages, such as Chichewa (Truckenbrodt 1999), Chitumbuka (Downing 2006), Chimwiini (Kisseberth 2000) or Xhosa (Zerbian 2004). As a first step, I will simply say that ALIGN-XP, R is ranked higher than the structural constraint *PPHRASE, defined in (22).

*P-PHRASE (Truckenbrodt 1999: 228)

Avoid p-phrases altogether

15 Depending on the language. For instance, the left edge is the relevant parameter In Ewe (Clements 1978), while the right edge is the relevant parameter in Chimwiini (Selkirk 1986). 
In the tableau (23), the candidate $b$ is rejected because it violates the constraint ALIGN-XP,R. The candidate $a$, which presents a phonological phrase boundary after the subject NP, emerges as the optimal candidate.

(23) Shingazidja

\begin{tabular}{|c|c|c|c|c|}
\hline & {$[\mathrm{NP}$} & $\mathrm{VP}]_{\mathrm{FP}}$ & ALIGN-XP,R & *P-PHRASE \\
\hline a. $\approx($ & $(\quad)_{\Phi}($ & ${\overline{\sigma_{\Phi}}}$ & & ** \\
\hline b. $\quad($ & & $\bar{\sigma}_{\Phi}$ & NP! & $*$ \\
\hline
\end{tabular}

There is no prosodic break between the verb and an indefinite object - see (15-ai), repeated in (24).

( ha-piha djánze $)_{\Phi}$

$3 \mathrm{sg}$ (past)-cook (5-)crab

he cooked a crab

In (25), the proposed ranking selects the appropriate candidate $b$ over the candidate $a$, which splits the VP.

(25) Shingazidja

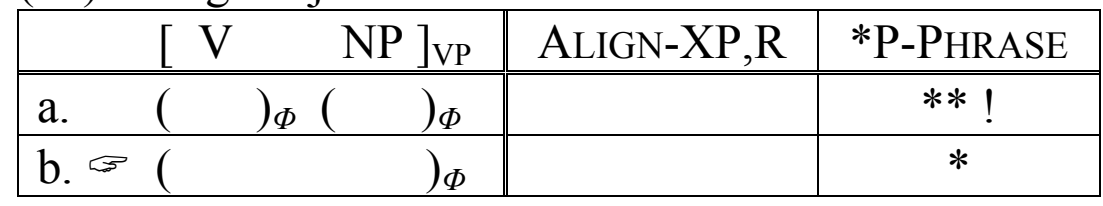

However, this ranking alone is not sufficient to account for all the attested phrasing patterns of Shingazidja. When a VP contains two objects - see (6-b), repeated in (26), the proposed ranking will incorrectly ${ }^{16}$ predict that a phonological phrase boundary is inserted after the first object náma (27).

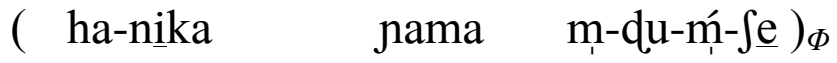

$$
\begin{aligned}
& 3 \mathrm{sg} \text { (past)-give 9/meat 1-person-1-woman }
\end{aligned}
$$

he gave (some) meat to a woman

(27) * Shingazidja

\begin{tabular}{|c|c|c|c|c|c|}
\hline & {$[\mathrm{I}$} & NP & $\mathrm{NP}]_{\mathrm{VP}}$ & ALIGN-XP,R & *P-PHRASE \\
\hline a. $\%$ & ( & )$_{\Phi}($ & )$_{\Phi}$ & & $* *$ \\
\hline b. & ( & & )$_{\Phi}$ & *! & $*$ \\
\hline
\end{tabular}

16 The selection of the 'wrong' candidate is marked by a bomb. 
To account for double-object constructions, another constraint is thus necessary: WRAP-XP, which will be introduced in the next section.

\subsection{Broad-focus sentences: double object constructions}

To account for the fact that the two objects of a VP phrase together in Chichewa and Papago (Uto-Aztecan; Hale \& Selkirk 1987), Truckenbrodt (1999: 228) introduced the constraint WRAP-XP, defined in (28).

(28) WRAP-XP (Truckenbrodt 1999: 228)

Each XP is contained in a phonological phrase

When WRAP-XP is ranked higher than alignment constraints, it prevents the insertion of a prosodic boundary inside any maximal XP. Then, the whole VP, or the whole NP, will phrase together. When WRAP-XP is ranked lower than alignment constraints, prosodic boundaries will be inserted inside the maximal XP, e.g. after each NP that it may contain.

However, a kind of prosodic structures does not violate either WRAP-XP nor alignment constraints: recursive structures. The recursive structure proposed in (29) does not violate WRAP-XP, since the maximal XP $\left(\mathrm{XP}_{1}\right)$ is contained in a single phonological phrase. Furthermore, it does not violate ALIGN-XP,R since a phonological phrase boundary follows the first embedded XP $\left(\mathrm{XP}_{2}\right)$. It has been demonstrated that recursive structures exist in the Bantu languages Kimatuumbi (Truckenbrodt 1999) and Chimwiini (Kisseberth 2000).

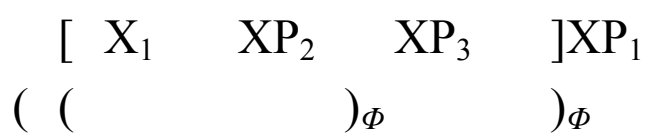

In Chichewa and Shingazidja, however, such a structure must be excluded, since no prosodic break separates the first object from the second object. To avoid recursive structures in Chichewa, Truckenbrodt (1999) proposed that the constraint NONRECURSIVITY, defined in (30), is high-ranked in this language.

(30) NONRECURSIVITY (Truckenbrodt 1999: 240)

Any two p-phrases that are not disjoint in extension are identical in extension 
This constraint "punishes recursive structure to the extent that the two elements of the recursive structure differ in extension" (Truckenbrodt 1999: 240-241). For instance, in (29), $\mathrm{XP}_{3}$ constitutes a violation of the constraint NONRECURSIVITY. In (31), the tableau proposed by Truckenbrodt (1999) to account for the phrasing of double-object constructions in Chichewa is presented. Candidates that present a phonological phrase boundary after the first object of the VP are ruled out by the constraints WRAP-XP and NONRECURISVITY.

(31) Chicheŵa (Truckenbrodt 1999: 246), Shingazidja

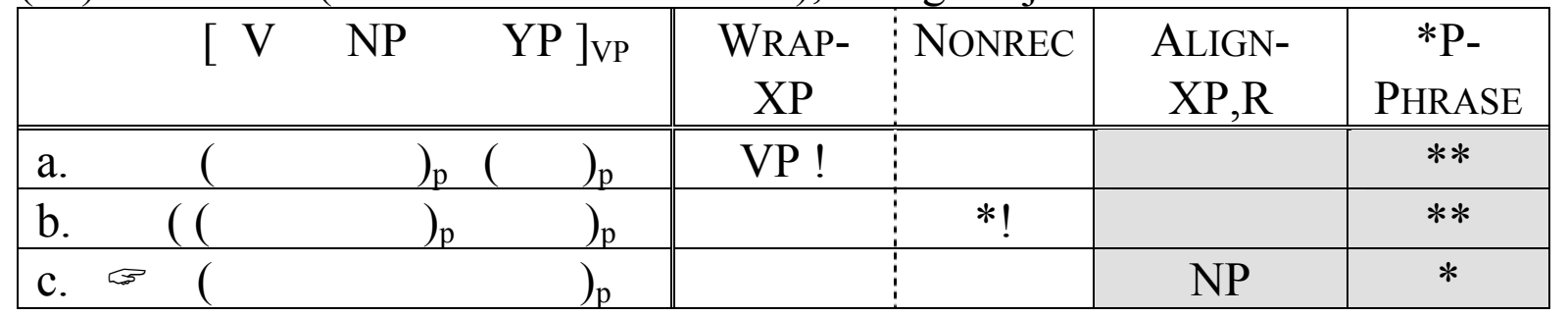

The candidate $a$ violates WRAP-XP since the VP is split in two different prosodic phrases. It is then excluded. The candidate $b$ does not violate WRAP-XP since the whole VP is contained in a single phonological phrase. However, it violates the constraint NONRECURSIVITY, and it is then excluded. NONRECURSIVITY has to be high-ranked in Chichewa to prevent the insertion of a prosodic boundary after the first object of the VP.

Since Chichewa and Shingazidja do not differ vis-à-vis the phrasing pattern of double-object constructions, I will retain temporarily Truckenbrodt's analysis.

\subsection{Narrow focus}

In Shingazidja, as in Chichewa, a focused word is followed by a phonological phrase boundary - see the example (15-a-ii), repeated in (32).

$$
\begin{aligned}
& \text { ( hapihá })_{\Phi} \quad(\text { djanzé })_{\Phi} \\
& 3 \operatorname{sg}(\text { past)-cook }(5-) \text { crab } \\
& \text { he COOKED a crab }
\end{aligned}
$$

To capture this fact, I will consider - following previous analyses of similar facts in several other Bantu languages ${ }^{17}$ - that the constraint ALIGN-Foc, proposed by Truckenbrodt (1999) and defined in (33), is ranked higher than basic alignment constraints in Shingazidja.

17 E.g. Truckenbrodt (1999) on Chicheŵa, Downing (2006, 2007) on Chitumbuka, Zerbian (2004) on Xhosa, etc. 
Align-FoC $=$ ALIGN(Foc, R; P, R) (Truckenbrodt 1999: 248)

Each focused constituent is right-aligned with a p-boundary

The analysis of VPs presenting a focused element is presented in the tableaux (34) and (36). At this point of the discussion, for reasons that will be clear later (cf. the section 4.4), I will not represent here the constraint NONRECURSIVITY.

In (34), the candidate $b$, which respects basic alignment constraints, is ruled out since it does not present a phonological phrase boundary after the focused element, i.e. the verb. The candidate $a$, even if it violates the constraint WRAP$\mathrm{XP}$, does not violate the high-ranked constraint ALIGN-FoC. Then, it is selected.

(34) Shingazidja

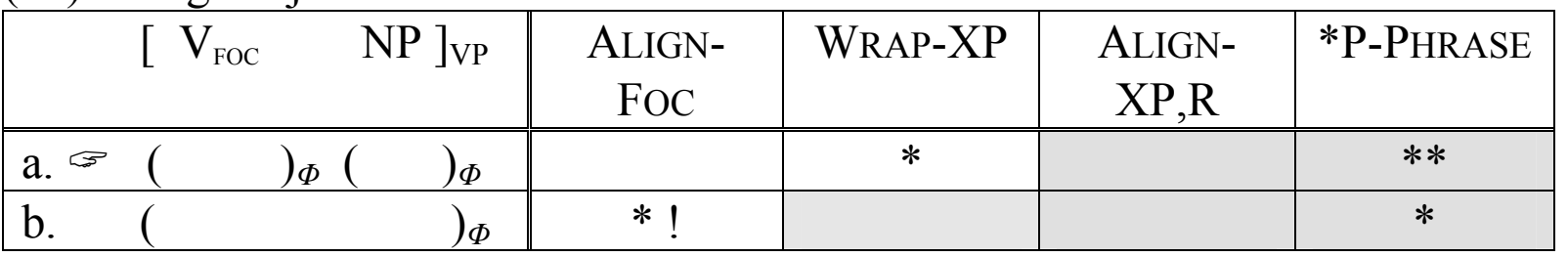

To allow the insertion of a prosodic boundary after a focused word, ALIGN-FOC has to outrank WRAP-XP.

The proposed ranking also selects the 'good' candidate when the first object is focused - see the example (13-b), repeated in (35). In the tableau (36), the high-ranked constraint ALIGN-FOC selects as optimal the candidate $a$.

$$
\begin{aligned}
& \text { b. } \begin{array}{l}
\text { hanika ndovú })_{\Phi} \quad(\text { mlevi })_{\Phi} \\
3 \operatorname{sg}(\text { past)-give }
\end{array} \\
& \text { 9-elephant } \quad \text { 1-drunkard } \\
& \text { he gave an ELEPHANT to a drunkard }
\end{aligned}
$$

\begin{tabular}{|c|c|c|c|c|c|c|}
\hline$[\mathrm{V}$ & $\mathrm{NP}_{\mathrm{FOC}}$ & $\mathrm{NP}]_{\mathrm{VP}}$ & $\begin{array}{c}\text { ALIGN- } \\
\text { FOC }\end{array}$ & $\begin{array}{c}\text { WRAP- } \\
\text { XP }\end{array}$ & $\begin{array}{c}\text { ALIGN- } \\
\text { XP,R }\end{array}$ & $\begin{array}{c}* \text { P- } \\
\text { PHRASE }\end{array}$ \\
\hline a. $\sigma($ & & )$_{\Phi}$ & & $*$ & & $* *$ \\
\hline b. & & )$_{\Phi}$ & $* !$ & & $*$ & $*$ \\
\hline
\end{tabular}

(36) Shingazidja

However, this ranking alone is not sufficient to account for all the situations that have been discussed in this paper. When the verb of a double-object VP is focused - see (17-b), repeated in (37) -, the proposed ranking will incorrectly predict that a prosodic boundary has to be inserted after the first object of the VP - cf. (38). 
$(\text { haniká })_{\Phi} \quad(\text { numbạ mlévi })_{\Phi}$

$3 \mathrm{sg}$ (past)-give (9-)house 1-drunkard

HE GAVE a house to a drunkard

(38) *Shingazidja

\begin{tabular}{|c|c|c|c|c|c|c|c|c|}
\hline & {$\left[\mathrm{V}_{\mathrm{FOC}}\right.$} & NP & & & $\begin{array}{c}\text { ALIGN- } \\
\text { FoC }\end{array}$ & $\begin{array}{c}\text { WRAP- } \\
\text { XP }\end{array}$ & $\begin{array}{c}\text { ALIGN- } \\
\text { XP,R }\end{array}$ & $\begin{array}{c}* \text { P- } \\
\text { PHRASE }\end{array}$ \\
\hline a. & ( & & & )$_{\Phi}$ & $* !$ & * & & $* *$ \\
\hline b. & ( & & & )$_{\Phi}$ & *! & & $*$ & $*$ \\
\hline c. $\sigma^{\prime \prime}$ & ( & & & )$_{\Phi}$ & & $*$ & & $* * *$ \\
\hline d. & ( & & & )$_{\Phi}$ & & * & $* !$ & $* *$ \\
\hline
\end{tabular}

WRAP-XP is a categorical constraint (Truckenbrodt 1995, 1999; SamekLodovici 2005): it can only be violated once, since its effect is neutralised as soon as a maximal XP is split in two different prosodic phrases. In (38), the candidate $c$ is selected because it does not violate the constraint ALIGN-XP,R, even if the whole VP is split in three different phrases. The 'good' candidate $d$ is ruled out because it violates this same constraint ALIGN-XP,R, even if the VP is minimally split.

Evidence for the categorical aspect of WRAP-XP comes from Chichewa data. In Chichewa (cf. 3.1.3), both the focused verb and the first object of a double-object construction are followed by a prosodic boundary, while all the words of the VP phrase together in broad-focus sentences. The model proposed by Truckenbrodt correctly predicts that the boundary that follows the first object will be allowed to emerge as soon as WRAP-XP is neutralised.

To account for the specificity of Shingazidja, I will then propose that focused elements are embedded in recursive structures.

\subsection{Verb focus in double object constructions: the hidden recursivity hypothesis}

The analysis of Chichewa proposed by Truckenbrodt is presented in (39).

(39) Chicheŵa (Truckenbrodt 1999: 249)

\begin{tabular}{|c|c|c|c|c|c|c|c|}
\hline & {$\left[\begin{array}{ll}\mathrm{V}_{\mathrm{FOC}} & \mathrm{NP}\end{array}\right.$} & $\mathrm{PP}]_{\mathrm{VP}}$ & $\begin{array}{c}\text { ALIGN- } \\
\text { FoC }\end{array}$ & $\begin{array}{l}\text { NON } \\
\text { REC }\end{array}$ & $\begin{array}{c}\text { WRAP- } \\
\text { XP }\end{array}$ & $\begin{array}{c}\text { ALIGN- } \\
\text { XP,R }\end{array}$ & $\begin{array}{c}* \text { P- } \\
\text { PHRA } \\
\text { SE }\end{array}$ \\
\hline a. & ( & $\partial_{p}$ & $* !$ & & & NP & $*$ \\
\hline b. & )$_{\mathrm{p}}($ & )$_{\mathrm{p}}$ & & & VP & NP! & $* *$ \\
\hline
\end{tabular}




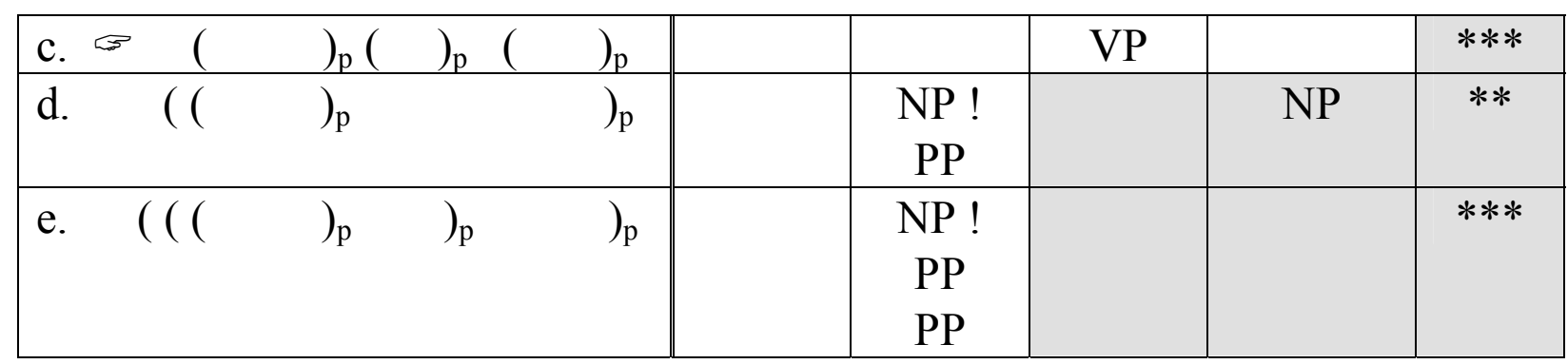

The tableau (39) is similar to the one proposed in (38) except that the constraint NONRECURSIVITY is added. The critical point, here, is the ranking of NONRECURSIVITY. Truckenbrodt (1999: 249-250) precise:

"To secure this result, a crucial ranking needs to be added that was not previously established for Chicheŵa: NONRECURSIVITY here has to outrank WRAP-XP. This can be seen by comparing candidates (c) and (d). The recursive structure in (d) allows ALIGN-FOC and WRAP-XP to be met simultaneously. However, candidate (d) must be ruled out since it does not include a right p-boundary after the first object, contrary to fact. Any constraint ruling out candidate (d) has to do so against the demands of WRAP-XP. Thus, (d) cannot be ruled out by ALIGN-XP,R, which is ranked below WRAP-XP for independent reasons [...]. NONRECURSIVITY, then, is the only constraint at hand that can rule out the phrasing in (d). For it to do so, NONRECURSIVITY has to be ranked above WRAP-XP [...]. This ranking then also eliminates other recursive candidates such as (e)."

To account for Shingazidja facts, I will then adopt the ranking rejected by Truckenbrodt in his analysis of Chichewa. I propose that Shingazidja presents recursive phonological phrases as soon as focus is involved.

Formally, I will suppose that WRAP-XP is ranked higher than NONRECURSIVITY in Shingazidja. This ranking selects as optimal the recursive candidate that does not include a prosodic break after the first object of the VP cf. (40). 
(40) Shingazidja

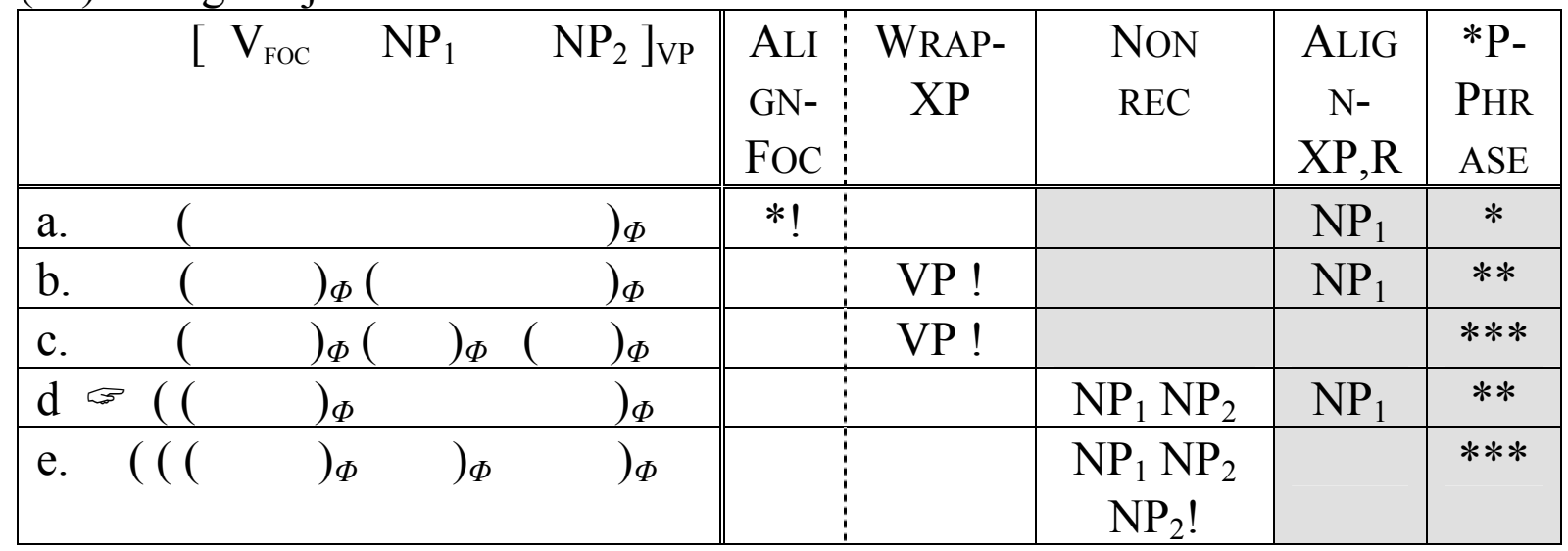

In (40), the candidates $b$ and $c$ are excluded because they violate the high-ranked constraint WRAP-XP. To respect both ALIGN-FOC and WRAP-XP, a candidate thus has to present a recursive structure. Then, the candidate $d$ is selected because it minimally violates the constraint NONRECURSIVITY.

When the first object bear a focus (cf. 35 above), the ranking also selects as optimal a recursive candidate. In (41), the candidate $b$, which was selected as optimal in the tableau (36), is now rejected because it violates the constraint WRAP-XP.

(41) Shingazidja

\begin{tabular}{|c|c|c|c|c|c|c|c|}
\hline$[\mathrm{V}$ & $\mathrm{NP}_{\mathrm{FOC}}$ & $\left.\mathrm{NP}_{2}\right]_{\mathrm{VP}}$ & $\begin{array}{c}\text { ALIGN- } \\
\text { FOC }\end{array}$ & $\begin{array}{l}\text { WRAP } \\
\text {-XP }\end{array}$ & $\begin{array}{l}\text { NON } \\
\text { REC }\end{array}$ & $\begin{array}{c}\text { ALIGN- } \\
\text { XP,R }\end{array}$ & $\begin{array}{c}* \text { P- } \\
\text { PHRA } \\
\text { SE }\end{array}$ \\
\hline a. & & )$_{\Phi}$ & *! & & & $\mathrm{NP}_{\mathrm{FOC}}$ & $*$ \\
\hline b. & & )$_{\Phi}$ & & VP! & & & $* *$ \\
\hline c. $\sigma(($ & & )$_{\Phi}$ & & & $\mathrm{NP}_{2}$ & & $* *$ \\
\hline d. $\quad($ & ( & )$_{\Phi}$ & & & $\mathrm{V} \mathrm{NP}_{2}$ ! & & $* *$ \\
\hline
\end{tabular}

Two candidates $-c$ and $d$ - respect both the constraint ALIGN-Foc and the constraint WRAP-XP. The candidate $d$ violates twice the gradient constraint NONRECURSIVITY: both the verb and the second object are excluded from the embedded phonological phrase. The candidate $c$ is then selected.

To sum up, I assume that the difference in phrasing between Chichewa and Shingazidja is related to the respective ranking of WRAP-XP and NONRECURSIVITY. While the former is dominated by the later in Chichewa (42a), the opposite ranking is proposed to account for Shingazidja data (42-b).

(42) Chicheŵa and Shingazidja rankings

a. Chicheŵa (Truckenbrodt 1995, 1999): 


$$
\begin{aligned}
& \text { ALIGN-FOC }>>\text { NONRECURSIVITY }>>\text { WRAP-XP }>\text { ALIGN-XP,R } \\
& >>\text { *P-PHRASE }
\end{aligned}
$$

b. Shingazidja:

$$
\begin{aligned}
& \text { Align-Foc, WRAP-XP }>\text { NONRECURSIVITY }>>\text { ALIGN-XP,R }>> \\
& \text { *P-PhraSE }
\end{aligned}
$$

\section{Summary}

In this paper, I have presented the main correlates of phrasing in Shingazidja. I have shown that focus conditions the phonological phrasing in Shingazidja. A phonological phrase boundary is inserted after a focused lexical item, resulting in restrictions on tone shift. This result is consistent with similar results obtained in several other Bantu languages.

The data was analysed in an OT-based framework, following Truckenbrodt's famous analysis of Chicheŵa. However, Shingazidja differs from Chichewa by phrasing together the two objects of a verb-focus sentence. I showed that the model can account for this specificity by reranking the constraint WRAP-XP over the constraint NONRECURSIVITY.

\section{References}

Cassimjee, Farida \& Charles Kisseberth (1998). Optimal Domains Theory and Bantu Tonology: a Case Study from Isixhosa and Shingazidja. In: Larry Hyman \& Charles Kisseberth (eds.), Theoretical Aspects of Bantu Tone. Stanford: CSLI, 33-132.

Cassimjee, Farida \& Charles Kisseberth (1993). The phrasal tonology of Shingazidja. 24th Annual Conference on African Linguistics. Ohio State University, July 23-25 1993.

Cassimjee, Farida \& Charles Kisseberth (1992). Metrical Structure in Shingazidja. CLS 28, 72-93.

Cassimjee, Farida \& Charles Kisseberth (1989). Shingazidja Nominal Accent. Studies in the Linguistic Sciences 19.1., 33-61.

Clements, Georges N. (1978). Tone and syntax in Ewe. In Donna Napoli (ed.), Elements of Tone, Stress, and Intonation. Washington, DC: Georgetown University Press, 21-99.

Chen, M. (1985) The syntax of phonology: Xiamen tone sandhi. MS, University of California, San Diego.

Cheng, Lisa \& Laura J. Downing (2007). The prosody and syntax of Zulu relative clauses. SOAS working papers in linguistics 15, 51-63.

Downing, Laura (2007). Focus prosody divorced from stress and intonation in Chichewa, Chitumbuka and Durban Zulu. ICPhS 2007 Satellite Meeting, Intonational Phonology: Understudied or Fieldwork Languages, Saarbrücken, August 52007. 
Downing, Laura (2006). The prosody and syntax of focus in Chitumbuka. ZAS Papers in Linguistics 43, 55-79.

Downing, Laura (2002). Fitting focus into the prosodic hierarchy. SOAS Working Papers in Linguistics, 111-133.

Downing, Laura, Al Mtenje \& Bernd Pompino-Marschall (2005). Prosody and Information Structure in Chichewa. ZAS Papers in Linguistics 37, 167-186.

Guthrie, Malcolm (1967-71) Comparative Bantu: an introduction to the comparative linguistics and prehistory of the Bantu languages. 4 vols. Farnborough: Gregg Press.

Hale, Ken \& Elisabeth Selkirk (1990). Government and Tonal Phrasing in Papago. Phonology Yearbook 4, 151-183.

Jackendoff, Ray (1972). Semantic Interpretation in Generative Grammar. Cambridge: MIT press.

Jokweni, Mbulelo (1995). Aspects of Isixhosa Phrasal Phonology. PhD dissertation, UrbanaChampaign, University of Illinois.

Jouannet, Francis (1989). Des tons à l'accent. Essai sur l'accentuation du comorien. Université de Provence Aix-Marseille.

Kanerva, Jonni (1990). Focus and Phrasing in Chichewa Phonology. New York: Garland.

Kisseberth, Charles (2007). Optimality Theory and the Theory of Phonological Phrasing: The Chimwiini Evidence. The Sound Patterns of Syntax, Research workshop of the Israel Science Foundation on the Syntax-Phonology Interface, Ben-Gurion University, June 11-13, 2007.

Kisseberth, Charles \& Mohammad Abasheikh (2004). The Chimwiini Lexicon Exemplified. Tokyo: Research Institute for Languages and Cultures of Asia and Africa (ILCAA).

Kula, Nancy (2007). Effects of phonological phrasing on syntactic structures. The Linguistic Review 24.2-3: Special Issue : Prosodic Phrasing and Tunes, 201-231.

McCarthy, John \& Alan Prince (1993a). Generalized Alignment. Yearbook of Morphology 1993, 79-153.

McCarthy, John \& Alan Prince (1993b). Prosodic Morphology I: Constraint interaction and satisfaction. Ms, University of Massachusetts, Amherst \& Rutgers University.

Patin, Cédric (2007a). La tonologie du shingazidja, langue bantu (G44a) de la Grande Comore : nature, formalisation, interfaces. Thèse de doctorat, Université Paris 3.

Patin, Cédric (2007b). Shingazidja focus hierarchy. Nouveaux Cahiers de linguistique francaise 28 Interfaces discours-prosodie, actes du 2ème Symposium international. Geneva, Switzerland, September 12-14 2007, 147-154.

Philippson, Gérard (2005). Pitch accent in Comorian and Proto-Sabaki tones. In Koen Bostoen \& Jacky Maniacky (eds.), Studies in African Comparative Linguistics with special focus on Bantu and Mande: Essays in Honour of Yvonne Bastin \& Claire Grégoire. Tervuren, Musée Royal de l'Afrique Centrale, 199-220. 
Philippson, Gérard (1991). Tons et accent dans les langues bantu d'Afrique orientale : étude typologique et diachronique. Thèse d'Etat, Université Paris V René Descartes, Paris.

Philippson, Gérard (1988). L'accentuation du comorien : essai d'analyse métrique. Etudes Océan Indien (Paris) 9, 35-79.

Prince, Alan \& Paul Smolensky (1993) Optimality Theory: Constraint Interaction in Generative Grammar. Rutgers University Center for Cognitive Science Technical Report 2.

Rey, Véronique (1990). Approche phonologique et expérimentale des faits d'accent d'une langue africaine, le shingazidja (parler de la Grande Comore). Thèse de doctorat, Université Aix-Marseille 1.

Samek-Lodovici, Vieri (2005). Prosody Syntax Interaction in the Expression of Focus. Natural Language and Linguistic Theory 23, 687-755.

Selkirk, Elisabeth (1995). The prosodic structure of function words. In Jill Beckman, Suzanne Urbanczyk \& Laura Walsh (eds.), Optimality Theory Occasional Papers: UMOP 18. Amherst: UMAS, 439-470.

Selkirk, Elisabeth (1986). On derived domains in sentence phonology. Phonology 3, 371-405.

Selkirk, Elisabeth \& Tong Shen (1990). Prosodic domains in Shanghai Chinese. In Sharon Inkelas \& Draga Zec (eds.), The Phonology-Syntax Connection. Chicago: Univerity of Chicago Press, 313-338.

Truckenbrodt, Hubert (1999). On the Relation between Syntactic Phrase and Phonological Phrases. Linguistic Inquiry 30, 219-255.

Truckenbrodt, Hubert (1995). Phonological Phrases: Their Relation to Syntax, Focus, and Prominence. Ph.D. dissertation, MIT.

Tucker, Archibald \& Margaret Bryan. (1970). Tonal classification of nouns in Ngazija. African Language Studies 11, 351-383.

Watters, John (1979). Focus in Aghem: a study of its formal correlates and typology. In Larry Hyman (ed.), Aghem grammatical structure. Southern California Occasional Papers in Linguistics 7. Los Angeles: University of Southern California, 137-97.

Zerbian, Sabine (2006). Expression of Information Structure in the Bantu Language Northern Sotho. PhD dissertation, Humboldt University, Berln.

Zerbian, Sabine (2004). Phonological Phrasing in Xhosa. In Susanne Fuchs \& Silke Hamann (eds.), ZAS Papers in Linguistics 37, 71-100. 